\title{
Eksplorasi Kebutuhan Bahan Ajar Mikrobiologi untuk Mahasiswa
}

\author{
Riza Nurhermi Ningtyas ${ }^{1}$, Endang Suarsini ${ }^{1}$, Mohamad Amin ${ }^{1}$ \\ ${ }^{1}$ Pendidikan Biologi-Universitas Negeri Malang
}

\begin{tabular}{l}
\hline \hline INFO ARTIKEL \\
\hline Riwayat Artikel: \\
Diterima: $21-05-2019$ \\
Disetujui: $13-09-2019$ \\
\hline
\end{tabular}

\section{Kata kunci:}

teaching materials; microbiology;

bioremediation;

bahan ajar;

mikrobiologi;

bioremediasi

\author{
Alamat Korespondensi: \\ Riza Nurhemi Ningtyas \\ Pendidikan Biologi \\ Universitas Negeri Malang \\ Jalan Semarang 5 Malang \\ E-mail: rizanurhermi2027@gmail.com
}

\begin{abstract}
ABSTRAK
Abstract: This study aims to explore teaching material of Microbiology in the material "Role of Microbes in Life (Bioremediation)" for students of Biology Education S1 Tribhuwana Tunggadewi University. This research is a qualitative descriptive study. Data collection techniques used is by distributing questionnaires. The results of the questionnaire showed that $84 \%$ stated that they needed to study more about the use of microbes in life (Bioremediation). 59\% of students used teaching materials based on research results and $70 \%$ of students stated that teaching materials in the form of modules made it easier to understand biological material. 57\% of students strongly agree if an $E$ module is developed. Based on these results it was concluded that teaching materials in the form of E-modules would be developed for Microbiology courses.
\end{abstract}

\begin{abstract}
Abstrak: Penelitian ini bertujuan untuk mengeksplorasi bahan ajar matakuliah Mikrobiologi pada materi "Peranan Mikroba dalam Kehidupan (Bioremediasi)" bagi mahasiswa S1 Pendidikan Biologi Universitas Tribhuwana Tunggadewi. Penelitian ini merupakan penelitian deskriptif kualitatif. Teknik pengumpulan data yang digunakan yaitu dengan penyebaran angket. Hasil angket menunjukkan bahwa $84 \%$ menyatakan perlu mengkaji lebih dalam tentang pemanfaatan mikroba dalam kehidupan (Bioremediasi). 59\% mahasiswa pernah menggunakan bahan ajar berbasis hasil penelitian dan $70 \%$ mahasiswa menyatakan bahwa bahan ajar berupa modul memudahkan dalam memahami materi Biologi. 57\% mahasiswa sangat setuju jika dikembangkan E-modul. Berdasarkan hasil tersebut disimpulkan bahwa perlu dikembangkan bahan ajar berupa E-modul untuk matakuliah Mikrobiologi.
\end{abstract}

Kurikulum untuk Pendidikan Tinggi mengacu pada Kerangka Kualifikasi Nasional Indonesia (KKNI) yang memiliki sembilan jenjang. Lulusan sarjana berada pada level VI, yaitu mahasiswa dituntut agar menguasai konsep teoritis secara umum dan khusus dalam bidang pengetahuan tertentu secara mendalam, serta mampu memformulasikan penyelesaian masalah prosedural sesuai dengan capaian pembelajaran (Kemenristekdikti, 2015). Universitas Tribhuwana Tunggadewi (UNITRI) Malang merupakan salah satu universitas negeri swasta di kota Malang yang baru membuka program studi Strata 1 Pendidikan Biologi. Mikrobiologi merupakan salah satu matakuliah yang ditempuh oleh mahasiswa angkatan 2017 di semester genap tahun ajaran 2018/2019. Capaian pembelajaran matakuliah ini yaitu mahasiswa mampu menjelaskan konsep dalam Mikrobiologi, mengenal sifat dan peranan mikroba dalam kehidupan sehari-hari, menjelaskan penerapan konsep Mikrobiologi dalam kehidupan sehari-hari dan menguasai teknik serta prosedur dasar laboratorium untuk mempelajari mikroba (Fidiastuti, 2018). Untuk memenuhi capaian pembelajaran, proses pembelajaran juga harus ditunjang dengan sarana dan prasarana yang memadai. Salah satu yang sarana yang dibutuhkan dalam proses pembelajaran adalah bahan ajar.

Bahan ajar merupakan seperangkat materi pelajaran yang disusun secara sistematis sesuai dengan kompetensi yang akan dicapai oleh peserta didik dalam kegiatan pembelajaran (Dick \& Carey, 1996) dan digunakan dalam proses pembelajaran dengan tujuan perencanaan dan penelaahan implementasi pembelajaran (Prastowo, 2011). Bahan ajar yang digunakan juga harus sesuai dengan tingkat pendidikan. Saat ini, bahan ajar yang dibutuhkan adalah bahan ajar yang berisi materi pembelajaran kontekstual yang disesuaikan dengan kehidupan nyata sehingga mahasiswa dapat membentuk atau mengonstruk pengetahuannya sendiri (Pribadi \& Sjarif, 2010; Suyono \& Hariyanto, 2011). Salah satu bentuk bahan ajar adalah modul.

Modul merupakan bahan ajar yang dapat memfasilitasi peserta didik dalam belajar (Citrawathi, Adnyana, \& Santiasa, 2016). Modul sebagai bahan ajar berisi materi pelajaran yang disusun dan disajikan tertulis sedemikian rupa sehingga pembacanya diharapkan mampu menyerap materi secara mandiri (Daryanto, 2013). Penggunaan modul sebagai bahan ajar menjadikan kegiatan belajar lebih terencana dengan baik, serta peserta didik dapat melakukan aktivitas belajar kapanpun dan dimanapun 
dengan atau tanpa bimbingan dari guru/dosen (Fitriyati, Mufti, \& Lestari, 2015). Pengembangan modul saat ini sudah berbasis elektronik atau yang bisa disebut dengan electronic modul (e-modul) (Ummah, Suarsini, \& Lestari, 2017). Kelebihan $e$-modul dibandingkan dengan modul cetak, di antaranya menjadikan proses pembelajaran lebih menarik, dilengkapi dengan gambar ataupun video dan mudah dalam penggunaannya (Suarsana \& Mahayukti, 2013; Ummah et al., 2017). Selain itu, materi dalam modul disusun sesuai dengan standard kompetensi (Daryanto, 2013). Tingkat perguruan tinggi, mahasiswa membutuhkan bahan ajar yang didalamnya terdapat contoh penelitian untuk menambah wawasan pengetahuan sehingga dapat diaplikasikan dalam kehidupan sehari-hari (Fitriyati et al., 2015).

Fenomena kehidupan yang berhubungan dengan matakuliah Mikrobiologi adalah pemanfaatan mikroorganisme di bidang lingkungan, yaitu proses bioremediasi. Bioremediasi merupakan proses penggunaan makhluk hidup seperti bakteri, fungi dan tanaman untuk menjaga dari komponen kimia di lingkungan. Bioremediasi dapat membersihkan lingkungan yang terkontaminasi polutan dengan menggunakan mikroorganisme hidup untuk dapat mendegradasi zat yang berbahaya menjadi zat yang memiliki kadar racun yang lebih sedikit (Ethica, 2018; Urry, Cain, Wasserman, Minorsky, \& Reece, 2016) Kemampuan suatu bakteri dalam melakukan degradasi suatu polutan tidak lepas dari adanya enzim yang dihasilkan. Adanya enzim tersebut tidak luput dari adanya gen yang menyandinya. Dengan kata lain, kemampuan suatu mikroba dalam mendegradasi suatu polutan dapat dikaji melalui pendekatan molekuler, yaitu analisis fungsi gen (Fahruddin, 2014).

Pembelajaran pada materi peranan mikroba dalam kehidupan matakuliah Mikrobiologi membutuhkan bahan ajar yang dapat menunjang perkuliahan tersebut, menyajikan konsep penting yang dapat dipelajari secara mandiri oleh mahasiswa untuk mengembangkan pengetahuannya. Tujuan penelitian ini adalah untuk mengeksplorasi kebutuhan bahan ajar untuk mahasiswa S1 prodi Pendidikan Biologi Tribhuwana Tunggadewi Malang. Hasil penelitian ini akan dijadikan sebagai dasar pengembangan bahan ajar pada topik peranan mikroba dalam kehidupan matakuliah Mikrobiologi di Universitas Tribhuwana Tunggadewi Malang.

\section{METODE}

Penelitian ini merupakan penelitian deskriptif kualitatif yang dilaksanakan pada bulan Januari 2019 di Universitas Tribhuwana Tunggadewi Malang. Subjek penelitian ini adalah mahasiswa Pendidikan Biologi angkatan 2017 Fakultas Ilmu Pendidikan Universitas Tribhuwana Tunggadewi Malang. Teknik pengumpulan data yaitu melalui penyebaran angket dengan jumlah responden sebanyak 45 mahasiswa yang menempuh matakuliah Mikrobiologi. Angket berisi 13 pertanyaan dengan beberapa indikator. Pertanyaan yang diajukan merupakan pertanyaan mengenai pembelajaran Biologi yang selama ini dilakukan. Hal ini dikarenakan matakuliah Mikrobiologi ini akan ditempuh pertama kalinya oleh mahasiswa angkatan 2017. Berikut adalah indikator pertanyaan yang terdapat pada tabel 1.

Tabel 1. Indikator Ekplorasi Mahasiswa Universitas Tribhuwana Tunggadewi Malang

\begin{tabular}{cl}
\hline No. & \multicolumn{1}{c}{ Indikator } \\
\hline 1. & Mengetahui persepketif mahasiswa tentang matakuliah Mikrobiologi \\
2. & Mengetahui sumber belajar, metode pembelajaran dan kekurangannya \\
3. & Menganalisis sumber belajar yang memudahkan dalam pembelajaran \\
4. & Menganalisis pengetahuan mahasiswa tentang peran mikroba dalam kehidupan (Bioremediasi) \\
\hline
\end{tabular}

\section{HASIL}

Hasil studi eksplorasi bahan ajar pada matakuliah Mikrobiologi yang dilakukan pada Januari 2019 di Universitas Tribhuwana Tunggadewi Malang (UNITRI) adalah sebagai berikut:

\section{Perspektif Mahasiswa tentang Matakuliah Mikrobiologi}

Angket perspektif mahasiswa tentang matakuliah Mikrobiologi digunakan untuk mengetahui pengetahuan awal mahasiswa yang akan menempuh matakuliah tersebut. Berdasarkan hasil angket, pengetahuan awal matakuliah Mikrobiologi hanya 25\% mahasiswa yang menjawab sangat sesuai dengan deskripsi Mikrobiologi, lainnya kurang sesuai dan $9 \%$ tidak menjawab. Namun, sebagian besar mahasiswa (87\%) berpendapat bahwa matakuliah Mikrobiologi sangat penting untuk dipelajari. Berikut adalah gambar grafik pengetahuan awal mahasiswa tentang matakuliah Mikrobiologi. 


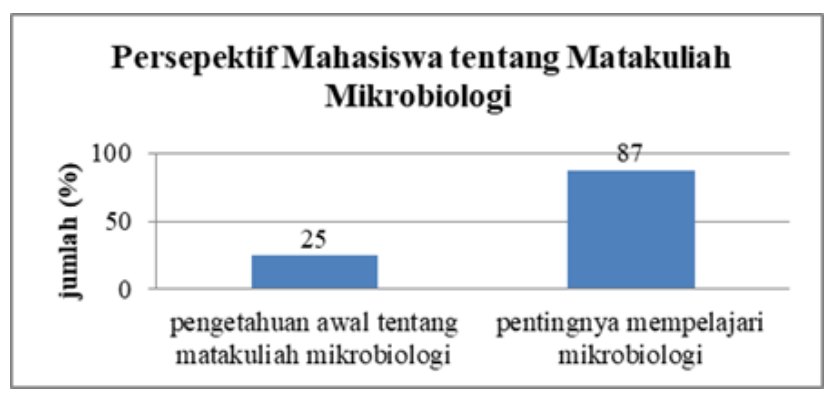

\section{Gambar 1. Grafik Hasil Analisis Perspektif Mahasiswa tentang Matakuliah Mikrobiologi}

\section{Sumber Belajar dan Metode Pembelajaran serta Kekurangannya}

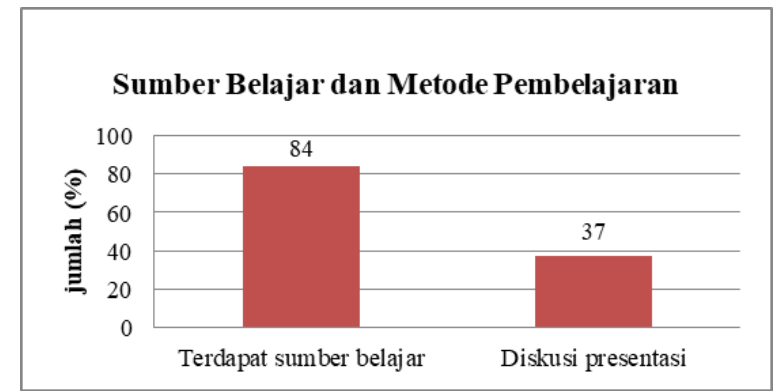

\section{Gambar 2. Grafik Hasil Analisis Sumber Belajar dan Metode Pembelajaran}

Berdasarkan gambar 2, hasil angket menunjukkan bahwa $84 \%$ mahasiswa menyatakan terdapat sumber belajar, yaitu yang berasal dari ceramah dosen di kelas, buku dan internet. Sumber belajar dari ceramah dosen didapatkan karena memang metode dalam pembelajaran didominasi oleh diskusi-presentasi, hal ini diungkapkan 37\% mahasiswa. Sumber belajar yang berasal dari internet memang mudah digunakan, namun kurang terpercaya. Sementara itu, sumber belajar berupa buku terdapat kekurangan yaitu buku yang digunakan kurang lengkap, tidak mudah untuk didapatkan, materi belum sesuai dengan kebutuhan dan membuat mahasiswa cepat bosan.

\section{Sumber Belajar yang Memudahkan dalam Pembelajaran}

Berdasarkan hasil angket sebanyak 59\% mahasiswa pernah menggunakan bahan ajar berbasis penelitian. Bahan ajar berbasis penelitian yang digunakan yaitu buku petunjuk praktikum. Bahan ajar memudahkan mahasiswa dalam belajar. Sebanyak $57 \%$ mahasiswa mempunyai keinginan untuk menggunakan bahan ajar yang berbasis penelitian dalam bentuk yang lain. Hal ini bisa dilihat pada gambar 3 .

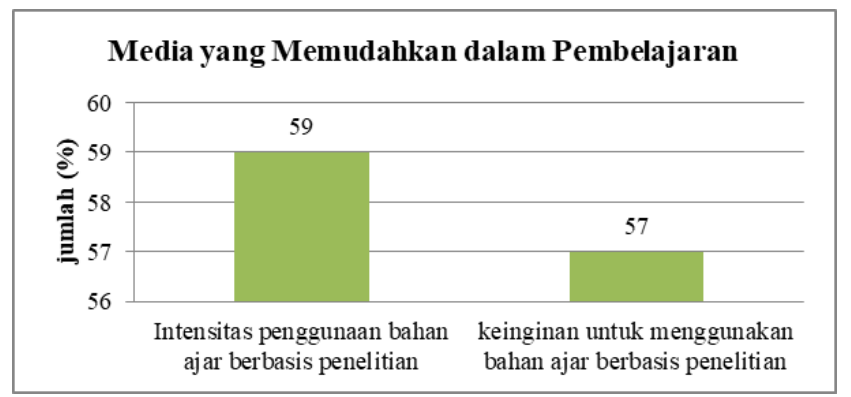

Gambar 3. Grafik Hasil Analisis Sumber Belajar yang Memudahkan dalam Pembelajaran 


\section{Pengetahuan Mahasiswa tentang Peranan Mikroba dalam Kehidupan}

Berdasarkan hasil analisis, diketahui bahwa 84\% mahasiswa memberikan respons perlunya mengkaji peranan mikroba dalam kehidupan. 39\% mahasiswa mengetahui gen bakteri sebagai kandidat bioremeditor dan 57\% mahasiswa sangat setuju apabila dikembangkan bahan ajar berbasis penelitian.

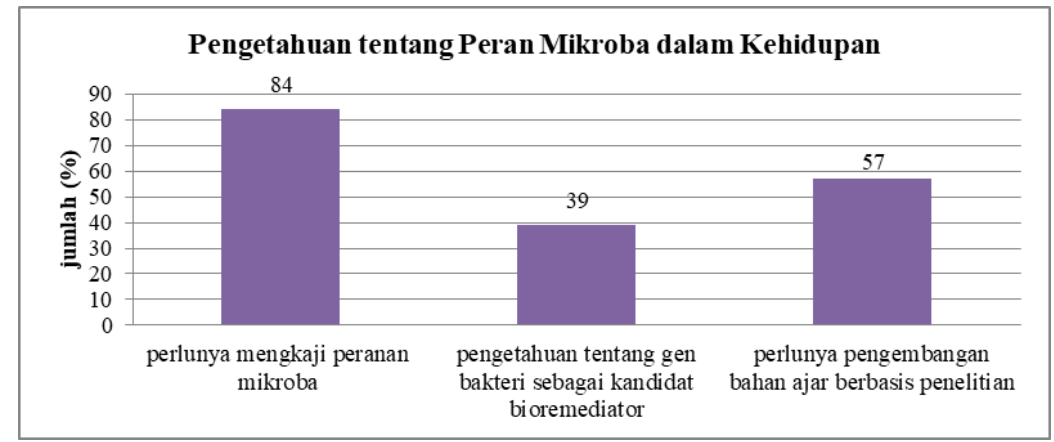

\section{Gambar 4. Grafik Hasil Analisis Pengetahuan tentang Peranan Mikroba dalam Kehidupan}

\section{PEMBAHASAN}

Berdasarkan hasil eksplorasi tersebut, mahasiswa masih banyak yang belum mengetahui tentang matakuliah Mikrobiologi. Hal ini dikarenakan mahasiswa belum menempuh matakuliah Mikrobiologi dan matakuliah tersebut baru akan ditempuh mahasiswa ini untuk pertama kalinya, namun mereka sudah mengetahui bahwa matakuliah Mikrobiologi merupakan matakuliah yang penting untuk dipelajari. Metode pembelajaran yang digunakan selama ini masih didominasi oleh diskusipresentasi sehingga proses pembelajaran terkesan monoton. Saat menggunakan metode tersebut hendaknya diiringi dengan penggunaan media atau sumber belajar yang menarik sehingga mahasiswa aktif berkontribusi dalam pembelajaran (Ummah et al., 2017). Penggunaan metode belajar yang tepat sangat penting dalam menunjang keberhasilan suatu proses pembelajaran (Al Aslahah, Amin, \& Gofur, 2017). Metode pembelajaran digunakan untuk mempermudah mahasiswa dalam proses belajar (memahami suatu bidang ilmu tersebut) (Dalyono, 2016)

Sumber belajar atau referensi yang digunakan kegiatan pembelajaran selama ini bersumber dari ceramah dosen, buku dan internet. Sumber belajar tersebut mudah digunakan, namun masih terdapat kekurangan, yaitu materi kurang lengkap, belum sesuai dengan kebutuhan, materi tidak mudah untuk didapatkan, dan mahasiswa cepat bosan. Ketersediaan sumber belajar merupakan komponen yang harus ada dalam pembelajaran (Andini, Hastuti, \& Gofur, 2017) dan unsur yang dapat meningkatkan kualitas suatu pembelajaran (Fahmi, Priwantororo, \& Astuti, 2018). Pemanfaatan sumber belajar yang beragam dapat menambah wawasan mahasiswa tentang bidang ilmu yang sedang dipelajari (Pribadi \& Sjarif, 2010). Sumber belajar merupakan bahan atau materi yang dapat menambah wawasan atau pengetahuan baru bagi mahasiswa (Asmadawati, 2014). Sumber belajar yang representatif merupakan sumber belajar yang menyajikan fenomena kehidupan sehari-hari yang dapat dieksplorasi oleh mahasiswa pada suatu materi pokok tertentu (Subiantoro \& Fatkurohman, 2009)

Hasil studi eksplorasi menunjukkan bahwa perlu adanya kajian tentang pemanfaatan mikroba dalam lingkungan. Materi Mikrobiologi yang membahas tentang pemanfaatan mikroba dalam kehidupan dibidang lingkungan (bioremediasi), merupakan materi yang membutuhkan contoh riil sehingga menjadikan pembelajaran yang kontekstual (sesuai dengan kehidupan nyata). Pembelajaran kontekstual dapat diperoleh dari hasil penelitian yang disajikan dalam bahan ajar dan dibelajarkan kepada mahasiswa (Rohmani, Amin, \& Lestari, 2017). Bahan ajar yang dianjurkan untuk mahasiswa adalah bahan ajar yang menyajikan materi secara utuh dan memberikan pengalaman nyata bagi mahasiswa untuk melakukan praktikum maupun penelitian dibidangnya sehingga dapat diaplikasikan dalam kehidupan sehari-hari. Bahan ajar tersebut merupakan bahan ajar berbasis penelitian (Fitriyati et al., 2015).

Berdasarkan hasil data eksplorasi tersebut, kendala terkait bahan ajar dapat diatasi dengan pengembangan bahan ajar berupa modul. Modul merupakan bahan ajar yang disusun secara sistematis menggunakan bahasa yang mudah dipahami agar peserta didik dapat belajar secara mandiri dengan bantuan atau bimbingan yang minimal dari pendidik (Prastowo, 2011). Modul dipilih karena dapat memfasilitasi mahasiswa untuk belajar mandiri ataupun dengan bantuan yang sedikit dari pendidik. Hal ini memang sesuai dengan tujuan pembuatan modul yaitu pembaca dapat menyerap materi atau bahan ajar secara mandiri (Self instruction), yang juga menjadi karakteristik modul. Karakteristik lain dari modul yang membedakan dengan bahan ajar lain yaitu self-contained (memuat materi yang lengkap dan spesifik), stand-alone (tidak bergantung pada media atau bahan ajar yang lain), adaptive (materi mengikuti alur perkembangan ilmu pengetahuan dan tekonologi), user friendly (mudah dalam menggunakannya) dan self-assessment (adanya evaluasi diri) (Daryanto, 2013). 
Sebagai salah satu bahan ajar dan perangkat pembelajaran, modul diyakini dapat memotivasi mahasiswa untuk belajar secara mandiri. Selain itu, aktivitas belajar yang dikemas dalam modul memicu mahasiswa untuk mengembangkan aspek kognitif maupun psikomotorik (Citrawathi et al., 2016). Berdasarkan data eksplorasi tersebut, banyak mahasiswa yang sudah pernah menggunakan bahan ajar berbasis hasil penelitian dan ingin menggunakan bahan ajar bentuk lainnya yang bisa digunakan secara mandiri dan memuat contoh riil untuk matakuliah Mikrobiologi. Bahan ajar berbasis penelitian yang digunakan selama ini yaitu berupa buku petunjuk praktikum. Bahan ajar berupa petunjuk praktikum hanya berisi prosedur dan tugas terstruktur (Andini et al., 2017). Bahan ajar yang baik adalah bahan ajar yang didalamnya terdapat pengetahuan (fakta, konsep, prinsip, dan prosedur), keterampilan, dan sikap (Prastowo, 2011). Selain itu, untuk mengurangi kejenuhan mahasiswa dalam belajar, maka bahan ajar berupa modul perlu dikombinasikan dengan media elektronik yang sering disebut electronic module (e-modul). Kelebihan emodul yaitu dapat meningkatkan efektivitas dan fleksibilitas pembelajaran, dapat meningkatkan motivasi belajar dan hasil belajar serta menjadikan pembelajaran menarik dan tidak cepat bosan karena dilengkapi dengan gambar, video maupun audio (Ummah et al., 2017). Oleh karena itu, bahan yang akan dikembangkan adalah modul yang berbasis hasil penelitian tentang isolasi gen bakteri kandidat bioremediator.

\section{SIMPULAN}

Berdasarkan hasil eksplorasi kebutuhan bahan ajar yang dilakukan pada mahasiswa S1 Prodi Pendidikan Biologi UNITRI, dapat disimpulkan bahwa perlu dikembangkan bahan ajar untuk matakuliah Mikrobiologi tentang pemanfaatan mikroba dalam kehidupan (bioremediasi). Bahan ajar yang perlu dikembangkan adalah modul elektronik (E-Modul).

Penelitian selanjutnya bisa dilakukan analisis kebutuhan bahan ajar atau metode pembelajaran yang dapat meningkatkan keterampilan abad 21 mahasiswa diantaranya yaitu keterampilan berpikir kritis, keterampilan berpikir kreatif, keterampilan komunikasi dan keterampilan kolaborasi.

\section{DAFTAR RUJUKAN}

Al Aslahah, B. H., Amin, M., \& Gofur, A. (2017). Kajian Kebutuhan Bahan Ajar Bioteknologi di Jurusan Biologi Universitas Negeri Malang. Pros. Seminar Pend. IPA Pascasarjana UM, 2, 416-420.

Andini, I. R., Hastuti, U. S., \& Gofur, A. (2017). Analisis Kebutuhan Bahan Ajar Matakuliah Mikrobiologi Mahasiswa S1 Pendidikan Biologi Universitas Ronggolawe Tuban. Pros. Seminar Pend. IPA Pascasarjana UM, 2, 455-461.

Asmadawati, A. (2014). Perencanaan Pengajaran. Jurnal Darul 'Ilmi, 02(01), 1-13.

Citrawathi, D. M., Adnyana, P. B., \& Santiasa, I. M. P. A. (2016). Analisis Kebutuhan untuk Pengembangan Modul Inkuiri Berbasis Pertanyaan (Mibp) di SMP. Jurnal Pendidikan Indonesia, 5(1), 764-774.

Dalyono, B. (2016). Strategi Pembelajaran Inovatif untuk Mencapai Kompetensi pembelajaran. Prosiding Temu Ilmiah Nasional Guru (TING) VIII, 29-41.

Daryanto, D. (2013). Menyusun Modul: Bahan Ajar untuk Persiapan Guru dalam Mengajar. Yogyakarta: Gava Media.

Ethica, S. N. (2018). Bioremediasi Limbah Biomedik. Yogyakarta: Deepublish.

Fahmi, S., Priwantororo, S. W., \& Astuti, D. (2018). Analisis Kebutuhan Pengembangan Multimedia. AdMathEdu, 8(1), 49-58. Fahruddin, F. (2014). Bioteknologi Lingkungan. Bandung: Alfabeta.

Fidiastuti, H. R. (2018). RPS Mikrobiologi. Malang: Universitas Tribhuwana Tunggadewi.

Fitriyati, U., Mufti, N., \& Lestari, U. (2015). Pengembangan Modul Berbasis Riset pada Matakuliah Bioteknologi. Jurnal Pendidikan Sains, 3(3), 118-129.

Prastowo, A. (2011). Panduan Kreatif Membuat Bahan Ajar Inovatif. Yogyakarta: Diva Press.

Pribadi, B. A., \& Sjarif, E. (2010). Pendekatan Konstruktivistik dan Pengembangan Bahan Ajar pada Sistem Pendidikan Jarak Jauh. Jurnal Pendidikan Terbuka dan Jarak Jauh, 11(2), 117-128.

Rohmani, M., Amin, M., \& Lestari, U. (2017). Analisis Kebutuhan Bahan Ajar Berbasis Penelitian Materi Bioteknologi Bidang Kedokteran untuk Mahasiswa S1 Pendidikan Biologi Universitas Negeri Malang Berdasarkan Model Pengembangan ADDIE. Prosiding Seminar Pendidikan IPA Pascasarjana UM, 2, 496-501.

Suarsana, I. M., \& Mahayukti, G. A. (2013). Pengembangan E-Modul Berorientasi Pemecahan Masalah Untuk Meningkatkan Keterampilan Berpikir Kritis Mahasiswa. Jurnal Pendidikan Indonesia, 2(2), 264-275.

Subiantoro, A. W., \& Fatkurohman, B. (2009). Keterampilan Berpikir Kritis Siswa Dalam Pembelajaran Biologi Menggunakan Media Koran. Jurnal Pendidikan Matematika Dan Sains, 2, 111-114.

Suyono \& Hariyanto. (2011). Belajar dan Pembelajaran: Teori dan Konsep Dasar. Bandung: PT. Remaja Rosdakarya.

Ummah, R., Suarsini, E., \& Lestari, S. R. (2017). Analisis Kebutuhan Pengembangan E-Modul Berbasis Penelitian Uji Antimikroba pada Mata Kuliah Mikrobiologi. Seminar Pendidikan IPA, 02, 555-562.

Urry, L. A., Cain, M. L., Wasserman, S. A., Minorsky, P. V., \& Reece, J. B. (2016). Campbell Biology (11th ed.). New York: Paerson Higher Education. 